\title{
Constitutive Equations and Processing Maps for 49MnVS3 Non-Quenched and Tempered Steel
}

\author{
Y. F. Chen, ${ }^{\mathrm{a}, \mathrm{b}, 1}$ X. D. Peng, ${ }^{\mathrm{a}, 2}$ H. B. Xu, ${ }^{\mathrm{b}, 3}$ H. D. Jiang, ${ }^{\mathrm{b}, 4}$ and G. H. Guan ${ }^{\mathrm{b5}}$ \\ ${ }^{a}$ School of Materials Science and Engineering, Chongqing University, Chongqing, China \\ b School of Materials Science and Engineering, Chongqing University of Technology, Chongqing, \\ China \\ ${ }^{1}$ chenyuanfang@cqut.edu.cn \\ 2 pengxiaodong@cqu.edu.cn \\ 3 xuhb@cqut.edu.cn \\ 4 307173732@qq.com \\ 5 Guohua Guan@cqut. edu.cn)
}

УДК 539.4

\section{Определяющие уравнения и схема обработки незакаленной и закаленной стали 49MnVS3}

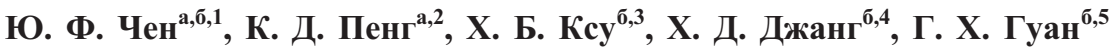 \\ а Факультет материаловедения и машиностроения, Чонгкинский университет, Чонгкинг, Китай \\ ${ }^{6}$ Факультет материаловедения и машиностроения, Чонгкинский технологический университет, \\ Чонгкинг, Китай
}

Изменение напряжения течения незакаленной и закаленной стали 49MnVS3 исследовали путем проведения испытаний на изотермическое сжатие на установке Gleeble-1500D, моделирующей высокотемпературные условия, при температурах деформации 950, 1000, 1150, $1200^{\circ} \mathrm{C}$ и скоростях деформации 0,$1 ; 1 ; 5$ и $10 c^{-1}$ с показателем степени деформационного упрочнения $n$ и значением энергии активации деформации сплава Q. Установлень определяющие уравнения и схемы обработки компрессионного режима течения для незакаленной $u$ закаленной стали 49MnVS3 при высокой температуре. Анализ уравнений показал, что максимальное значение напряжения значительно уменьшается при снижении скорости деформации и повышении температуры деформации, если сплав подвергается деформации при высокой температуре, а значение энергии активации деформаџии составляет 350,98 кДж/моль. Если значения истинной деформаџии незакаленной стали 49MnVS3 и высокотемпературной деформации микролегированной стали составляют 0,5, то оптимальные параметры процесса обработки сплава определяются при температуре деформирования $1150 \ldots 1200^{\circ} \mathrm{C} \mathrm{и} \mathrm{скорости}$ деформации $2 \ldots 10 c^{-1}$ на основе критерия, который способствует отбору параметров $c$ более высокой эффективностью рассеивания мощности в области динамической рекристаллизачии в качестве оптимальной технологии обработки.

Ключевые слова: незакаленная и закаленная сталь 49MnVS3, напряжение потока, определяющее уравнение, схема обработки.

Introduction. 49MnVS3 non-quenched and tempered steel is a microalloyed mediumcarbon steel with microstructure of ferrite and pearlite. There is tiny vanadium-containing precipitated phase in pro-eutectoid ferrite and pearlite. The 49MnVS3 alloy has been applied to various significant parts in automobiles, engineering machinery and machine 
tools due to its excellent comprehensive performance, such as manufacture of critical automotive parts of bent axle, knuckle spindle and constant velocity cardan joints at hot forging state without quenching and tempering treatment. However, the plasticity of $49 \mathrm{MnVS} 3$ alloy processed at room temperature is poor. Thereby, the plastic processing is generally performed at high temperatures, usually employing forging as the processing technique $[1,2]$.

The flow stress value of the metal in the plastic processing is not only an important index to measure plastic processing capacity of material, but is also the basis of equipment selection and basic premise of design of mold and related devices. The flow stress in thermal deformation is one of the basic material properties at high temperatures, occupying extremely important positions in terms of developing a reasonable thermal processing technology, as well as theoretical research in the plastic deformation of metals [3]. The constitutive equations of materials describe the quantitative relationships between flow stress and strain and between strain rate and temperature deformation in material deformation. Thus, the constitutive equations are the basic data for developing thermal processing technology and are also instrumental for the finite element method to simulate manufacturing process $[4,5]$. The thermal processing map is superposition of dynamic material model-based energy consumption diagram and instability diagram, and is capable of proper description of the relation between structural change and plasticity parameters of the material deformation at high temperatures, providing the option range for determining process parameters in the alloy deformation $[6,7]$.

The $49 \mathrm{MnVS} 3$ steel is non-quenched and tempered steel which is widely used for crankshaft of heavy-duty automobile. The aim of present investigation was to establish the constitutive equations and processing maps for the thermal deformation behavior of the alloy by calculating and simulating the stress and strain data of 49MnVS3 non-quenched and tempered steel obtained at different temperatures and strain rates via thermal simulated test machine, and supply the theoretical basis for the selection of processing parameters in alloy deformation.

1. Experimental Materials and Test Methods. The tested material is $49 \mathrm{MnVS} 3$ non-quenched and tempered steel under hot-rolled state with composition of $\mathrm{Si} \leq 0.6 \%$, $0.6 \% \leq \mathrm{Mn} \leq 1.0 \%, \mathrm{P} \leq 0.035 \%, 0.045 \% \leq \mathrm{S} \leq 0.065 \%, 0.008 \leq \mathrm{V} \leq 0.13 \%$, and $0.42 \% \leq \mathrm{C}$ $\leq 0.50 \%$.

The thermally compressed specimen taken from the air-cooled hot-rolled bar is subjected to isothermal compression test on Gleeble1500D thermal simulated test machine. The specimen for compression test has a size of $\varnothing 10 \times 12 \mathrm{~mm}$ with $0.2 \mathrm{~mm}$-deep grooves at both ends. In order to reduce influence of friction on the stress state, graphite is casted to both ends of the specimen, and then graphite sheets are pasted to the ends. The deformation temperature is set as $950,1000,1150$, and $1200^{\circ} \mathrm{C}$, and strain rate is set as $0.1,1,5$, and $10 \mathrm{~s}^{-1}$, respectively. At first, the tested specimen is heated to $1250^{\circ} \mathrm{C}$ with heating rate of $10{ }^{\circ} \mathrm{C} / \mathrm{s}$ and then incubated for $3 \mathrm{~min}$ at $1250^{\circ} \mathrm{C}$. Then the specimen is cooled to the deformation temperature with a rate of $5{ }^{\circ} \mathrm{C} / \mathrm{s}$ and incubated for $30 \mathrm{~s}$ at deformation temperature, in order to eliminate the temperature gradient. Finally, the isothermal deformation proceeds at deformation temperature. Argon protection is used to prevent the surface of the specimen from oxidation. After the deformation is finished, water quenching starts immediately. The strain rate is kept constant during the compression process. The temperature is automatically compensated by computer system of Gleeble1500D thermal simulated test machine and is maintained constant. The data on stress, strain, and temperature are collected automatically by Gleeble1500D thermal simulated test machine so as to plot curve of true stress-true strain.

\section{Results and Discussion.}

2.1. True Stress-True Strain Curve. Figure 1 shows the true stress-true strain curve of isothermal compression of $49 \mathrm{MnVS} 3$ non-quenched and tempered steel. As can be seen 


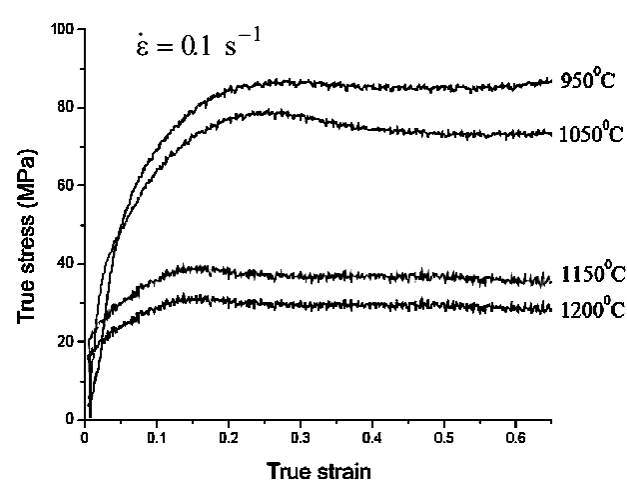

a

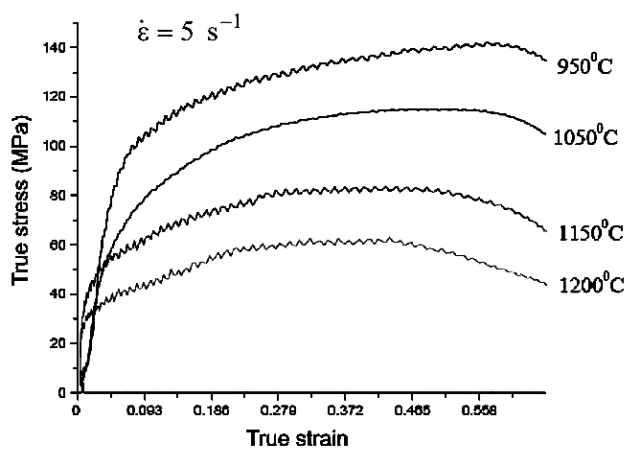

$\mathrm{c}$

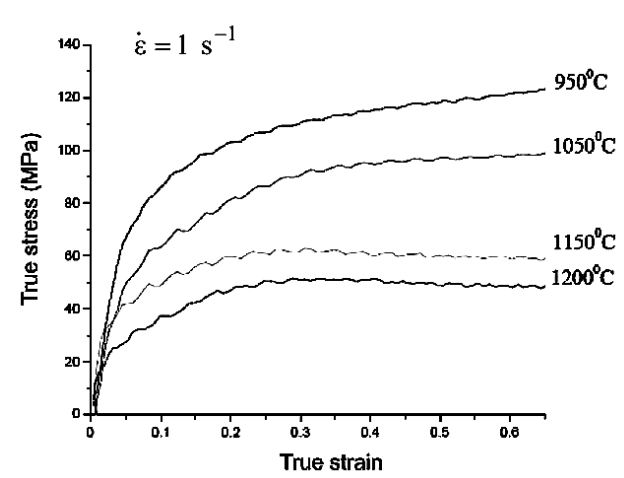

$\mathrm{b}$

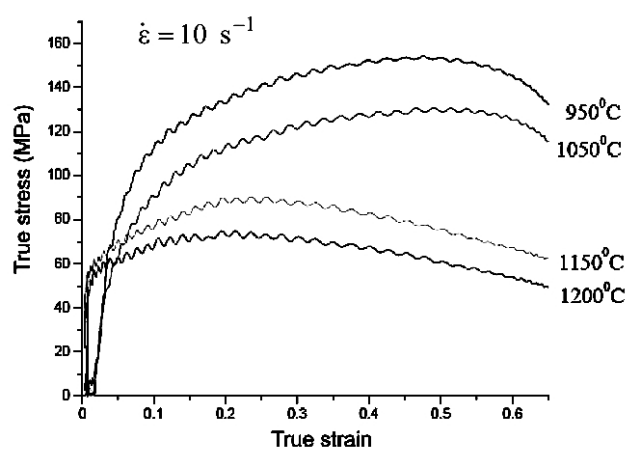

d

Fig. 1. True stress-strain curves of $49 \mathrm{MnVS} 3$ steel during hot compression.

from Fig. 1, the process parameters, such as heating temperature, deformation and strain rate, have a significant impact on the flow stress.

During the thermal compression deformation of 49MnVS3 non-quenched and tempered steel, the flow stress increase first rapidly and then slower with the increase of strain. Under higher temperatures and lower strain rates, the stress is gradually decreased after peak value appears and the peak stress gradually decreases with rise of deformation temperature when the strain rate is constant. Under lower temperatures and higher strain rates, the stress shows a slow upward trend instead of the apparent stress peak, and the material deformation exhibits a significant dynamic softening phenomenon as the temperature rises. In the experimental temperature range, the flow stress increases with the lift of strain rate in case of constant temperature.

2.2. Establishment of Constitutive Equation. The strain rate is an important factor affecting the flow stress. As can be seen from Fig. 1, under the same deformation temperature, the stress level of the material is increased with the rise of strain rate, indicating that the material is positively sensitive to strain rate. The reported studies have demonstrated that there are various expressions to describe relationship between the strain rate of the flow stress and deformation temperature under the high temperature deformation $[4,5,8,9]$, such as exponential relationship, power exponent relationship and hyperbolic sine formula, revealed as follows:

$$
\dot{\varepsilon}=A_{1} \sigma^{n_{1}} \exp \left(\frac{-Q}{R T}\right),
$$




$$
\begin{gathered}
\dot{\varepsilon}=A_{2} \exp (\beta \sigma) \exp \left(\frac{-Q}{R T}\right), \\
\dot{\varepsilon}=A[\sinh (\alpha \sigma)]^{n} \exp \left(\frac{-Q}{R T}\right),
\end{gathered}
$$

where $\dot{\varepsilon}$ is strain rate, $A$ is structural factor, $A_{1}$ and $A_{2}$ are constants, $n_{1}$ and $\beta$ are material constants, $\alpha$ is parameter of stress level, $\sigma$ is material flow stress, $n$ is hardening exponent of stress, $Q$ is deformation activation energy which reflects the ease or difficulty of material thermal deformation, $R$ is molar gas constant, and $T$ is the absolute deformation temperature.

Taking the natural logarithm on both sides of formulas (1) and (2), respectively, the following equations can be obtained:

$$
\begin{gathered}
\ln \dot{\varepsilon}=\ln A_{1}+n_{1} \ln \sigma-\frac{Q}{R T}, \\
\ln \dot{\varepsilon}=\ln A_{2}+\beta \sigma-\frac{Q}{R T} .
\end{gathered}
$$

From formula (4) and (5) it can be seen that $n_{1}=\frac{\partial \ln \dot{\varepsilon}}{\partial \ln \sigma}$ and $\beta=\frac{\partial \ln \dot{\varepsilon}}{\partial \sigma}$. Based on the experimental data of flow stress and strain rate under different compression conditions, the corresponding relational graphs of $\ln \dot{\varepsilon}-\ln \sigma_{p}$ and $\ln \dot{\varepsilon}-\sigma_{p}$ are plotted as shown in Fig. 2, wherein the value of $\sigma_{p}$ is set as peak stress.

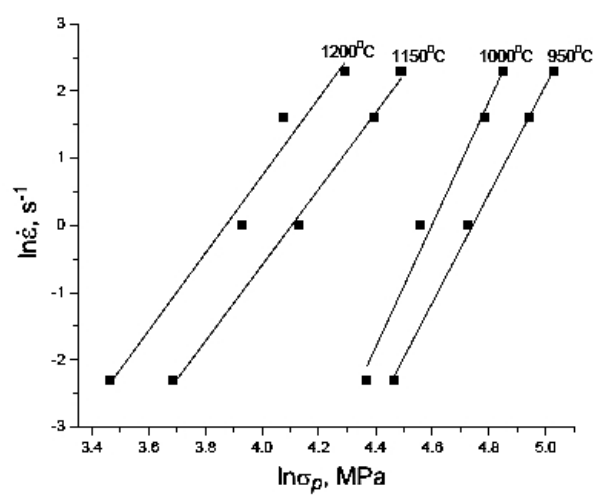

a

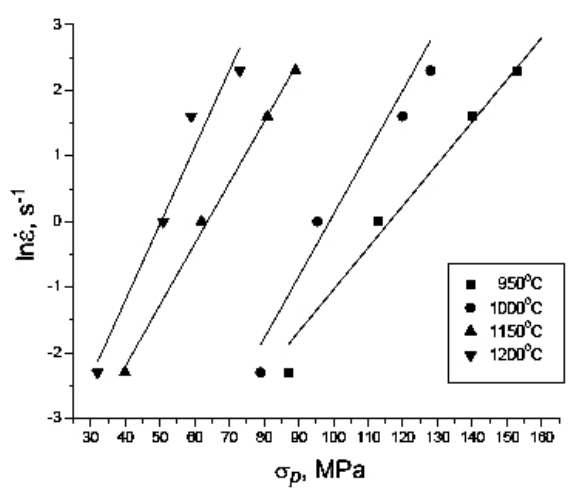

b

Fig. 2. Relation between strain rate and peak stress of 49MnVS3 steel.

It can be seen from formulas (4) and (5) that $\ln \dot{\varepsilon}$ is linearly related to $\sigma_{p}$ and $\ln \sigma_{p}$. The values of $n_{1}$ and $\beta$ can be calculated as the average slopes through monadic linear regression with the minimum multiplication, respectively. The slopes of the curves in Fig. 2 mean values of $n_{1}$ and $\beta$, respectively. $n_{1}=7.4375$ and $\beta=0.0825 \mathrm{MPa}^{-1}$ are obtained by calculating and averaging. Then, $\alpha=\beta / n_{1}=0.011092$.

Taking the natural logarithm on both sides of formula (3) and assuming that deformation activation energy is irrelevant of temperature, when the temperature is constant, the following relation can be obtained: 


$$
\ln \dot{\varepsilon}+\frac{Q}{R T}=\ln A+n \ln [\sinh (\alpha \sigma)] .
$$

It can be found from formula (6) that $\ln \dot{\varepsilon}$ and $\ln [\sinh (\alpha \sigma)]$ have a linear relationship whose slope is the stress hardening index $n$. On the basis of true stress-strain curve of $49 \mathrm{MnVS} 3$ non-quenched and tempered steel and a constant strain of $50 \%$, a straight line is fitted out with $\ln [\sinh (\alpha \sigma)]$ as $x$ coordinate and $\ln \dot{\varepsilon}$ as $y$ coordinate, as shown in Fig. 3. The stress exponent $n=5.44$ is acquired by calculating the slope of the curves in Fig. 3 and taking the average. Thus, the strain rate sensitivity index $m=1 / n=0.1838$ is obtained.

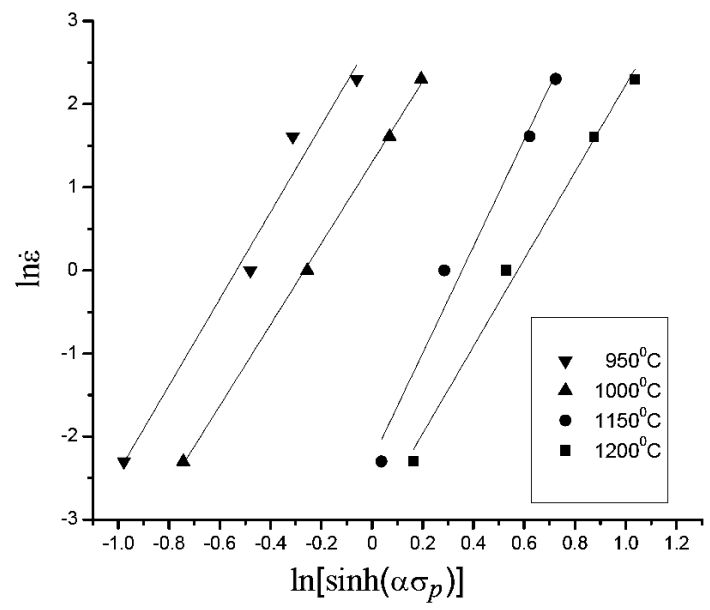

Fig. 3. Relation between strain rate and flow stress for $49 \mathrm{MnVS} 3$ steel.

Under a constant strain rate, assuming that $Q$ remains unchanged within a certain temperature range, and taking the logarithm on both sides of formula (3), the following equation can be obtained:

$$
\ln [\sinh (\alpha \sigma)]=\frac{1}{n} \ln \frac{\dot{\varepsilon}}{A}+\frac{1}{n} \frac{Q}{R T} .
$$

As can be seen from formula (7), $\ln [\sinh (\alpha \sigma)]$ has a linear relationship with $1 / T$. Through fixing the strain as $50 \%$ and incorporating the values of peak stress under different deformation conditions into formula (7), linear regression is conducted to draw the corresponding $\ln \left[\sinh \left(\alpha \sigma_{p}\right)\right]-1 / T$ curve, obtaining the relational graph between flow stress and deformation temperature as shown in Fig. 4.

Figure 4 indicates that for the same rheological rate, a linear relationship exists between the logarithm of hyperbolic sine of flow stress and the reciprocal of temperature, suggesting that $\sigma$ and $T$ fairly meet the linear relationship of formula (7), demonstrating that under high-temperature deformation the relationship between flow stress $\sigma$ of 49MnVS3 non-quenched and tempered steel and deformation temperature $T$ satisfies the Arrehenius relation, and also stating that the thermal compression plasticity deformation of $49 \mathrm{MnVS} 3$ non-quenched and tempered steel is also controlled by the heat-activated reaction.

Treating the data in Fig. 4 by linear regression analysis, an average slope of 0.77 is obtained for the four curves, that is

$$
\frac{Q}{R n}=0.77
$$




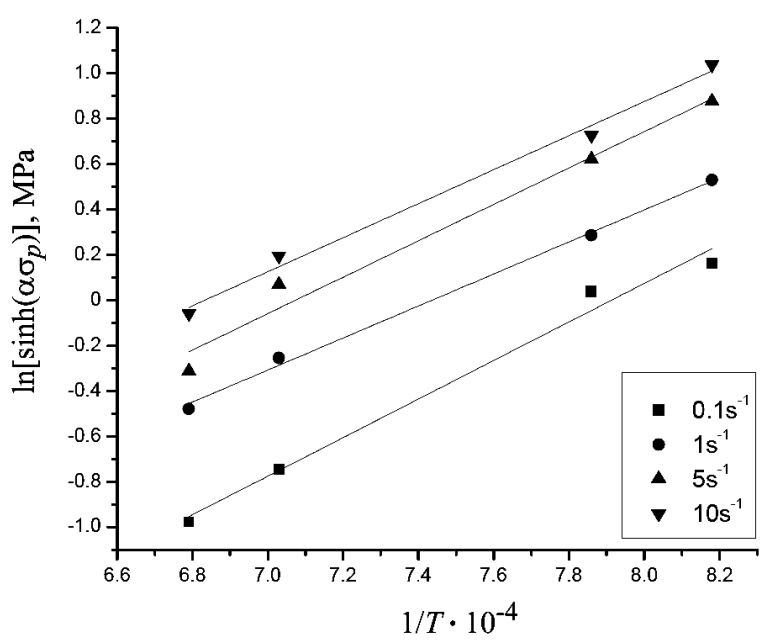

Fig. 4. Relation between flow stress and temperature of 49MnVS3 steel.

Through formula (8) the deformation activation energy $Q$ of 49MnVS3 non-quenched and tempered steel is calculated to be $350.98 \mathrm{~kJ} / \mathrm{mol}$.

According to the definition of Zener-Hollomon parameter, formula (9) can be derived:

$$
Z=\dot{\varepsilon} \exp [Q /(R T)]
$$

Taking natural logarithm on both sides of formula (9), the following equation is established:

$$
\ln Z=\ln \dot{\varepsilon}+\frac{Q}{R T} .
$$

By inserting the deformation activation energy $Q$ and deformation conditions into formula (10), the corresponding values of $\ln Z$ under different test conditions can be calculated (Table 1).

T a b 1 e 1

In $Z$ Values of 49MnVS3 Non-Quenched and Tempered Steel under Different Deformation Conditions

\begin{tabular}{|c|c|c|c|c||}
\hline \multirow{2}{*}{$\begin{array}{c}\text { Strain rate } \\
\dot{\varepsilon}, \mathrm{s}^{-1}\end{array}$} & \multicolumn{4}{|c||}{ Temperature $T, \mathrm{~K}$} \\
\cline { 2 - 5 } & 1223 & 1273 & 1423 & 1473 \\
\hline 0.1 & 32.2154 & 30.8597 & 27.3640 & 26.3570 \\
\hline 1 & 34.5180 & 33.1623 & 29.6666 & 28.6596 \\
\hline 5 & 36.1275 & 34.7717 & 31.2760 & 30.2690 \\
\hline 10 & 36.8206 & 35.4648 & 31.9692 & 30.9622 \\
\hline
\end{tabular}

By combining Eqs. (3) and (9), it can be obtained that

$$
Z=\dot{\varepsilon} \exp [Q / R T]=A[\sinh (\alpha \sigma)]^{n} .
$$


Formula (12) is presented as follows by taking natural logarithm on both sides of formula (11):

$$
\ln [\sinh (\alpha \sigma)]=\frac{1}{n} \ln Z+\frac{1}{n} \ln A .
$$

Substituting $\sigma$ into formula (12) with steady-state stress $\sigma_{s s}$, and utilizing $\ln \left[\sinh \left(\alpha \sigma_{s S}\right)\right]$ and $\ln Z$ to the plot, the relationship between flow stress and $Z$ parameter is acquired, as shown in Fig. 5.

According to the definition of hyperbolic sine function, formula (12) is solved to obtain

$$
\sigma=\frac{1}{\alpha} \ln \left\{(Z / A)^{1 / n}+\left[(Z / A)^{2 / n}+1\right]^{1 / 2}\right\} .
$$

It can be seen from formula (12) that $1 / n$ is the slope of $\ln \left[\sinh \left(\alpha \sigma_{s s}\right)\right]-\ln Z$ curve, while $(1 / n) \ln A$ is the intercept. Disposing the data in Fig. 5 with linear regression analysis, the average slope of the straight line is obtained to be 0.1894 , that is $1 / n=0.1894$, thus $n=5.28$, and the average intercept of the straight line is acquired as -6.06 , that is $(1 / n) \ln (A-1)=-6.06$, then $A=7.8711 \cdot 10^{13}$.

$\mathrm{T}$ a b 1 e 2

\section{Calculation of Parameters in Modeling Process for Flow Stress of Non-Quenched and Tempered 49MnVS3 Steel}

\begin{tabular}{||l|c||}
\hline \multicolumn{1}{|c|}{ Parameter } & Value \\
\hline Hardening exponent of stress $n$ & 5.28 \\
\hline Parameter of stress level $\alpha$ & 0.011092 \\
\hline Deformation activation energy $Q, \mathrm{~kJ} / \mathrm{mol}$ & 350.98 \\
\hline Structure factor $A$ & $7.8711 \cdot 10^{13}$ \\
\hline
\end{tabular}

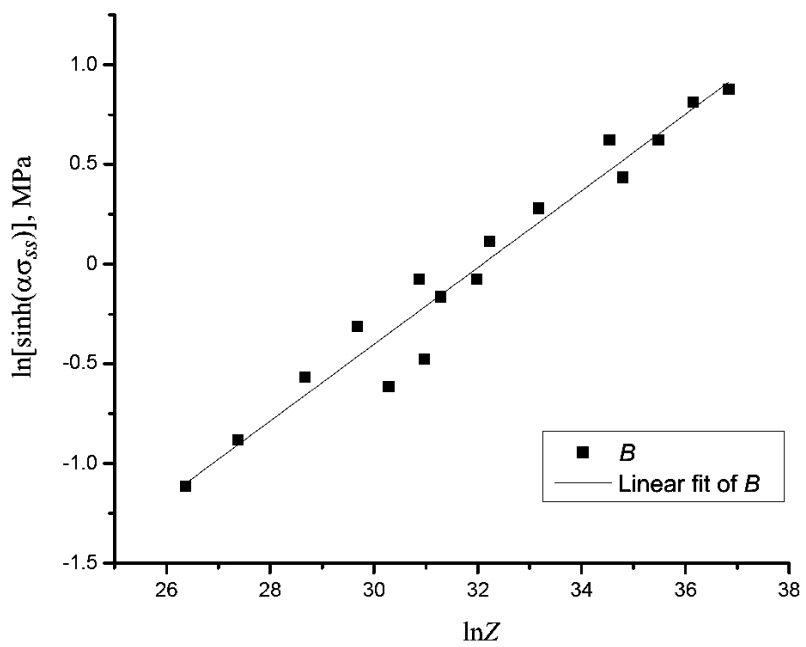

Fig. 5. Relation between flow stress and parameter $Z$.

The material parameter values of $n, \alpha, Q$, and $A$ (Table 2) are incorporated into Eq. (3) to obtain the Arrehenius equation for non-quenched and tempered 49MnVS3 steel under thermal compression, as shown in (14): 


$$
\dot{\varepsilon}=7.8711 \cdot 10^{13}[\sinh (0.0115 \sigma)]^{5.28} \exp \left(\frac{-350980}{R T}\right) .
$$

The material parameter values of $n, \alpha, Q$, and $A$ are put into Eq. (13) to obtain the expression for $Z$ parameter of steady-state flow stress of 49MnVS3 non-quenched and tempered steel under thermal compression, as seen from formula (15):

$$
\sigma=\frac{1}{0.0115} \ln \left\{\left(\frac{Z}{7.8711 \cdot 10^{13}}\right)^{1 / 5.28}+\left[\left(\frac{Z}{7.8711 \cdot 10^{13}}\right)^{2 / 5.28}+1\right]^{1 / 2}\right\},
$$

where $Z=\dot{\varepsilon} \exp \left(\frac{350980}{R T}\right)$.

Formula (14) is the constitutive equation of $49 \mathrm{MnVS} 3$ non-quenched and tempered steel under high-temperature conditions. Formula (15) is a high-temperature flow stress model of $49 \mathrm{MnVS} 3$ non-quenched and tempered steel.

\subsection{Construction and Analysis of Processing Map.}

2.3.1. Theory of Processing Map. In the dynamic material model, the thermal processing material is considered as a nonlinear energy dissipation body. The power $P$ absorbed by the material of unit volume per unit time in the thermal processing is converted into two parts, including power $G$ dissipated by plastic deformation and power $J$ consumed by the structure change in deformation process $[10,11]$. The relation between $G$ and $J$ can be expressed by the following equation:

$$
\begin{gathered}
\frac{J}{G}=\frac{\partial(\log \sigma)}{\partial(\log \dot{\varepsilon})}=m, \\
P=\sigma \dot{\varepsilon}=G+J=\int_{0}^{\dot{\varepsilon}} \sigma d \dot{\varepsilon}+\int_{0}^{\sigma} \dot{\varepsilon} d \sigma .
\end{gathered}
$$

Here $m$ is the sensitivity factor of strain rate. Under certain temperature and strain conditions, the stress $\sigma$ born by the workpiece during thermal processing and strain rate $\dot{\varepsilon}$ are related as follows:

$$
\sigma=K \dot{\varepsilon}^{m}
$$

The above equation is a dynamic constitutive equation.

By substituting formula (18) into (16) and combining formula (17), the following equation is obtained [11]:

$$
J=\sigma \dot{\varepsilon}-\int_{0}^{\dot{\varepsilon}} k \dot{\varepsilon}^{m} d \dot{\varepsilon}=\frac{m}{m+1} \sigma \dot{\varepsilon}
$$

When the material is in the ideal linear dissipative state, $m=1$, then $J$ reaches the maximum value, that is $J_{\max }=J(m=1)=\sigma / 2$. The dimensionless parameter $J / J_{\max }$ that reflects the power dissipation characteristic of material is defined as $\eta$, and is termed as energy dissipation efficiency factor. Value of $\eta$ can reflect microstructure deformation mechanism of material for certain deformation temperature and rate [12], and is expressed with the strain rate sensitivity factor as follows: 


$$
\eta=\frac{2 m}{m+1} \text {. }
$$

The instability graph is based on the extremum principle of irreversible thermodynamics. The dimensionless parameter $\xi(\dot{\varepsilon})$ is used to represent the criterion for continuous instability under large-scale plastic deformation. Prasad obtained the instability criterion according to the maximum entropy principle of material [13]:

$$
\xi(\dot{\varepsilon})=\frac{\partial \ln [m(m+1)]}{\partial \ln \dot{\varepsilon}}+m<0 .
$$

2.3.2. Plotting of Processing Map. The values of true stress under strain of 0.5 , different deformation temperatures and various deformation conditions are supposed to be calculated by fitting curves in Fig. 1 with a cubic polynomial. The fitting function is as follows:

$$
\log \sigma=a+b \log \dot{\varepsilon}+c(\log \dot{\varepsilon})^{2}+d(\log \dot{\varepsilon})^{3} .
$$

The curve $\log \sigma-\log \dot{\varepsilon}$ is shown in Fig. 6. The values of $a, b, c$, and $d$ in the fitting function can be determined. It can be obtained from formula (17) that

$$
m=\frac{\partial(\log \sigma)}{\partial(\log \dot{\varepsilon})}=b+2 c \log \dot{\varepsilon}+3 d(\log \dot{\varepsilon})^{2} .
$$

There the sensitivity factor $m$ under different conditions can be gained from the values of strain rate. Moreover, the values of dissipation efficiency factor $\eta$ at different deformation temperatures and different strain rates can be obtained through equation (20). Then the equivalent contour line of power dissipation efficiency factor $\eta$ is drawn in the $T-\log \dot{\varepsilon}$ plane, that is the power dissipation efficiency map. Substituting formula (23) into (21), the variable $\xi(\dot{\varepsilon})$ is expressed as

$$
\xi(\dot{\varepsilon})=\frac{\partial \log \left(\frac{m}{m+1}\right)}{\partial \log \dot{\varepsilon}}+m=\frac{2 c+6 d(\log \dot{\varepsilon})}{m(m+1) \ln 10}+m .
$$

By deriving the values of $\xi(\dot{\varepsilon})$ under different deformation conditions, the rheological instability graph can be obtained for a certain deformation temperature and a strain rate. Then the processing map can be obtained by superimposing power dissipation graph with instability graph, as shown in Fig. 7, wherein the shadow area is the instability region [that is the zone of $\xi(\dot{\varepsilon})<0]$, and the contours line represents the order of magnitude of the values of energy dissipation efficiency $\eta$.

2.3.3. Analysis of Processing Map. When the plastic deformation of the alloy proceeds with the corresponding process parameters in the rheological instability region, there will be a variety of defects. Thus thermal processing should be avoided in this region. As can be seen from Fig. 7 , as the strain is 0.5 , three instability zones (that is the three shadow areas) appear under the thermal deformation of the alloy. Moreover, the safe processing region comprises three regions, including region I with strain rate of $2-10 \mathrm{~s}^{-1}$ and temperature of $950-1050^{\circ} \mathrm{C}$, region II with strain rate of $0.1-0.5 \mathrm{~s}^{-1}$ and temperature of $1075-1175^{\circ} \mathrm{C}$, and region III with strain rate of $2-10 \mathrm{~s}^{-1}$ and temperature of $1150-1200^{\circ} \mathrm{C}$. The contour line in Fig. 7 represents the dissipation efficiency factor. It can be discovered that the value of 


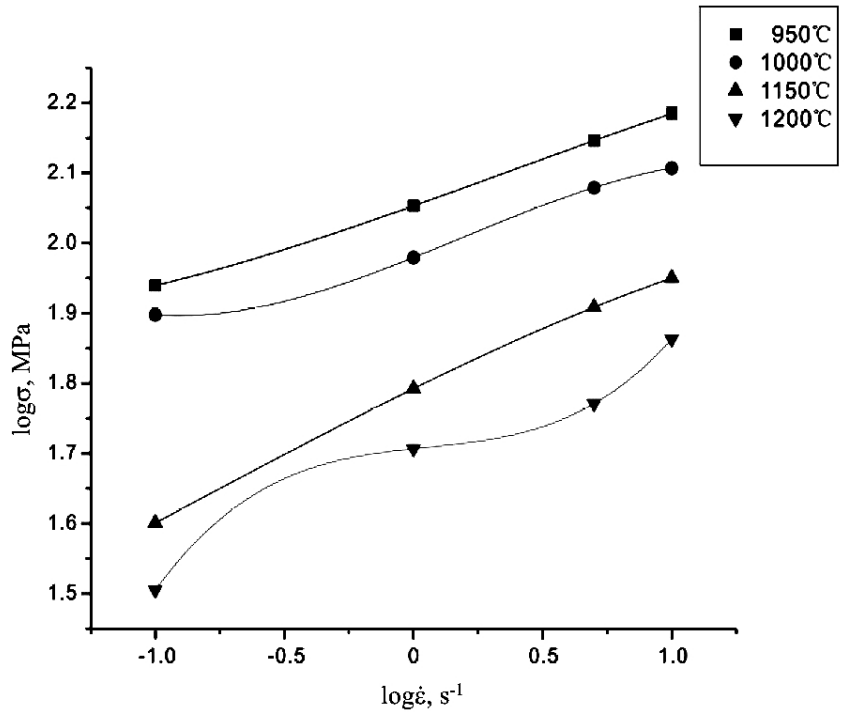

Fig. 6. The interpolating curves obtained from stress and strain rate values.

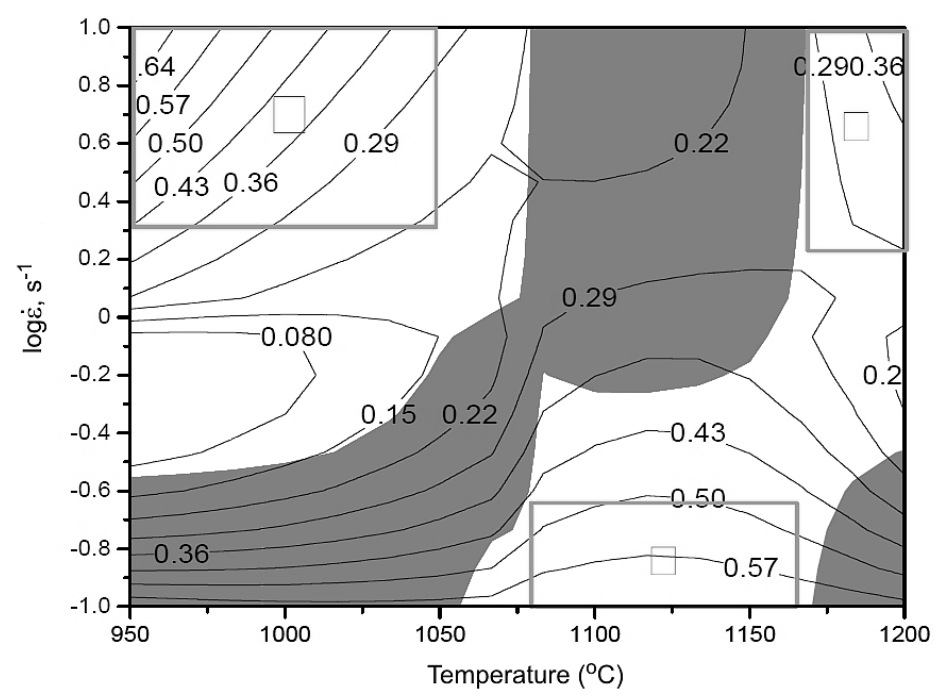

Fig. 7. Processing map of $49 \mathrm{MnVS} 3$ steel at 0.5 true strain.

energy dissipation efficiency factor varies in different parts, implying that the deformation temperature and strain rate have impact on the alloy dynamic consumption. The deformation of alloy in the low-temperature region is inclined to cause the flow strain localization and thus initiate shear cracking [14].

The higher dissipation efficiency factor does not necessarily mean that the processing conditions are more suitable for processing. It can be found from Fig. 7 that although the dominated region of higher values belongs to safe processing area, part of the region is the instability zone and is unfit for thermal processing. Remarkably, there is a criterion that the processing parameters of greater power dissipation efficiency values in dynamic recrystallization region should be chosen as the best processing technology. According to Fig. 7, as the strain is 0.5 , the optimum thermal processing parameters for this alloy lie in the region of deformation temperature of $1150-1200^{\circ} \mathrm{C}$ and strain rate of $2-10 \mathrm{~s}^{-1}$. 
Conclusions. Hot deformation behavior of 49MnVS3 non-quenched and tempered steel was analyzed by constitutive equations and processing map. The most noteworthy results are listed below:

1. In the temperature range of $950-1200^{\circ} \mathrm{C}$, the high-temperature compression deformation behavior of $49 \mathrm{MnVS} 3$ non-quenched and tempered steel is greatly influenced by deformation temperature and strain rate. At the same deformation temperature, flow stress increases with the rising of strain rate. In case of the same strain rate, the flow stress decreases with increase of deformation temperature.

2. The basic material constants of 49MnVS3 non-quenched and tempered steel under high-temperature deformation are calculated by analyzing the flow stress, obtaining structure factor $A=7.8711 \cdot 10^{13}$, the parameter $\alpha$ of stress level of 0.0115 , stress hardening exponent $n=5.28$, thermal deformation activation energy $Q=350.98 \mathrm{~kJ} / \mathrm{mol}$, and a hyperbolic sine relation for the high-temperature flow stress.

3. For $49 \mathrm{MnVS} 3$ non-quenched and tempered steel under high-temperature compression condition, the flow stress relates with temperature and strain rate.

4. When true strain of non-quenched and tempered microalloyed $49 \mathrm{MnVS} 3$ steel is 0.5 , the optimum parameters' range of thermal processing for this alloy is determined to be deformation temperature of $1150-1200^{\circ} \mathrm{C}$ and strain rate of $2-10 \mathrm{~s}^{-1}$, according to the guideline that the optimal processing parameters should be selected from the processing parameters of greater power dissipation efficiency values in dynamic recrystallization region.

Acknowledgements. This paper is subsidized by the following project funding: The National Natural Science Fund, Project Number: 51275548, Chongqing Science and Technology Natural Science Fund Project: cstc2012jjb70002, the project of Chongqing Scientific and Technology No. 2009AA3012-2 and Chongqing Municipal Education Commission Applied Basic Research Program of China (KJ120833).

\section{Резюме}

Зміну напруження течії незагартованої і загартованої сталі 49MnVS3 досліджували шляхом проведення випробувань на ізотермічний стиск на установці Gleeble-1500D, що моделює високотемпературні умови, за температур деформації 950, 1000, 1150, $1200^{\circ} \mathrm{C}$ та швидкості деформації 0,$1 ; 1 ; 5 \mathrm{i} 10 \mathrm{c}^{-1}$ із показником степеня деформаційного зміцнення $n$ і значенням енергії активації деформації сплаву $Q$. Установлено визначальні рівняння і схеми обробки компресійного режиму течії для незагартованої і загартованої сталі 49MnVS3 за високої температури. Аналіз рівнянь показав, що максимальне значення напруження значно зменшується зі зниженням швидкості деформації і підвищенні температури деформації, якщо сплав зазнає деформації за високої температури, а значення енергії активації деформації дорівнює 350,98 кДж/моль. Якщо значення істинної деформації незагартованої сталі 49MnVS3 і високотемпературної деформації мікролегованої сталі дорівнюють 0,5, то оптимальні параметри процесу обробки сплаву визначаються за температури деформування $1150 \ldots 1200^{\circ} \mathrm{C}$ і швидкості деформації $2 \ldots 10 \mathrm{c}^{-1}$ на основі критерію, який сприяє відбору параметрів із більш високою ефективністю розсіяння потужності в області динамічної рекристалізації як оптимальної технології обробки.

1. J. Ding, "Present situation of application and development of microalloyed steel for automobile," Heat Treat. Metals, 31, No. 9, 46-48 (2006).

2. Zhaojiu Gen, Miao Yong, Tangxin Min, and Chenjian Ye, "Development of a microalloy steel for vehicle front axle," Auto. Technol. Mater., 7, 15-17 (2000). 
3. X. M. Tang, J. Y. Chen, J. G. Zhao, et al., "Development and application of non-quenched and tempered steels of bending and extending arms," Heat Treat. Metals, 1, 45-47 (2001).

4. H. Shi, A. J. McLaren, C. M. Sellars, et al., "Constitutive equations for high temperature flow stress of aluminum alloys," Mater. Sci. Technol., 13, 210-216 (1997).

5. A. Laasraoui and J. J. Jonas, "Recrystallization of austenite after deformation at high temperature and strain rates-analysis and modeling," Metall. Trans., 22A, 151-160 (1991).

6. A. Laasraoui and J. J. Jonas, "Prediction of steel flow stresses at high temperatures and strain rates," Metall. Trans., 22A, No. 7, 1545-1558 (1991).

7. C. M. Sellars, "Computer modelling of hot-working processes," Mater. Sci. Technol., 1, No. 4, 325-332 (1985).

8. C. M. Sellars and W. J. McTegart, "On the mechanism of hot deformation," Acta Metall., 14, No. 9, 1136-1138 (1966).

9. C. M. Sellars, "Modeling microstructural development during hot rolling," Mater. Sci. Technol., 6, 1072-1081 (1990).

10. Z. M. Zhang, B. C. Yang, K. L. Liu, et al., "Numerical simulation of alloy ZTC4 can isothermal extrusion," J. Plasticity Eng., 11, No. 3, 31-34 (2004).

11. Y. V. R. K. Prasad and S. Sasidhara, Hot Working Guide: A Compendium of Processing Maps, ASM International, Materials Park, OH (1997).

12. B. Bozzini and E. Cerri, "Numerical reliability of hot working processing maps," Mater. Sci. Eng. A, 328, No. 1-2, 344-347 (2002).

13. Y. V. R. K. Prasad and T. Seshacharyulu, "Modelling of hot deformation for microstructure control," Int. Mater. Rev., 43, No. 6, 243-258 (1998).

14. R. Raj, "Development of a processing map for use in warm-forming and hot-forming processing," Metall. Trans., 12, No. 6, 1089-1097 (1981). 